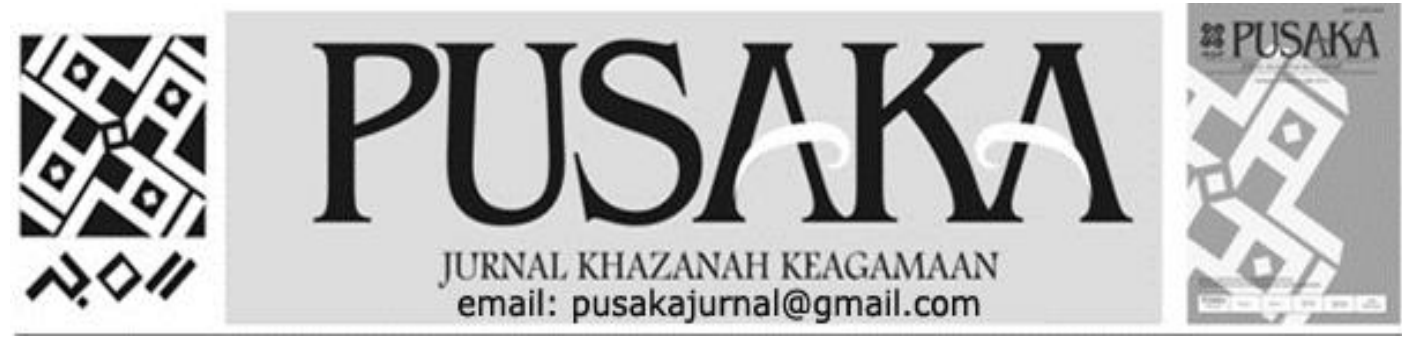

\title{
Altruisme Islam, Transplantasi dan Donasi Organ: Pergumulan Agama dalam Wacana dan Praktiknya di Indonesia
}

\section{Islamic Altruism, Transplantation and Organ Donation: The Struggle of Religion in Discourse and Practice in Indonesia}

\author{
Mahyuddin ${ }^{1,}$ Abd. Halim K ${ }^{2,}$ Iskandar $^{3}$ \\ 1,2,3 Institut Agama Islam Negeri Parepare \\ Jl. Amal Bakti No. 08 Soreang, Kota Parepare \\ Email: Mahyuddin@iainpare.ac.id ${ }_{2}^{1}$ Habdhalimk@iainpare.ac.id ${ }^{2}$, \\ Iskandar@iainpare.ac.id ${ }^{3}$
}

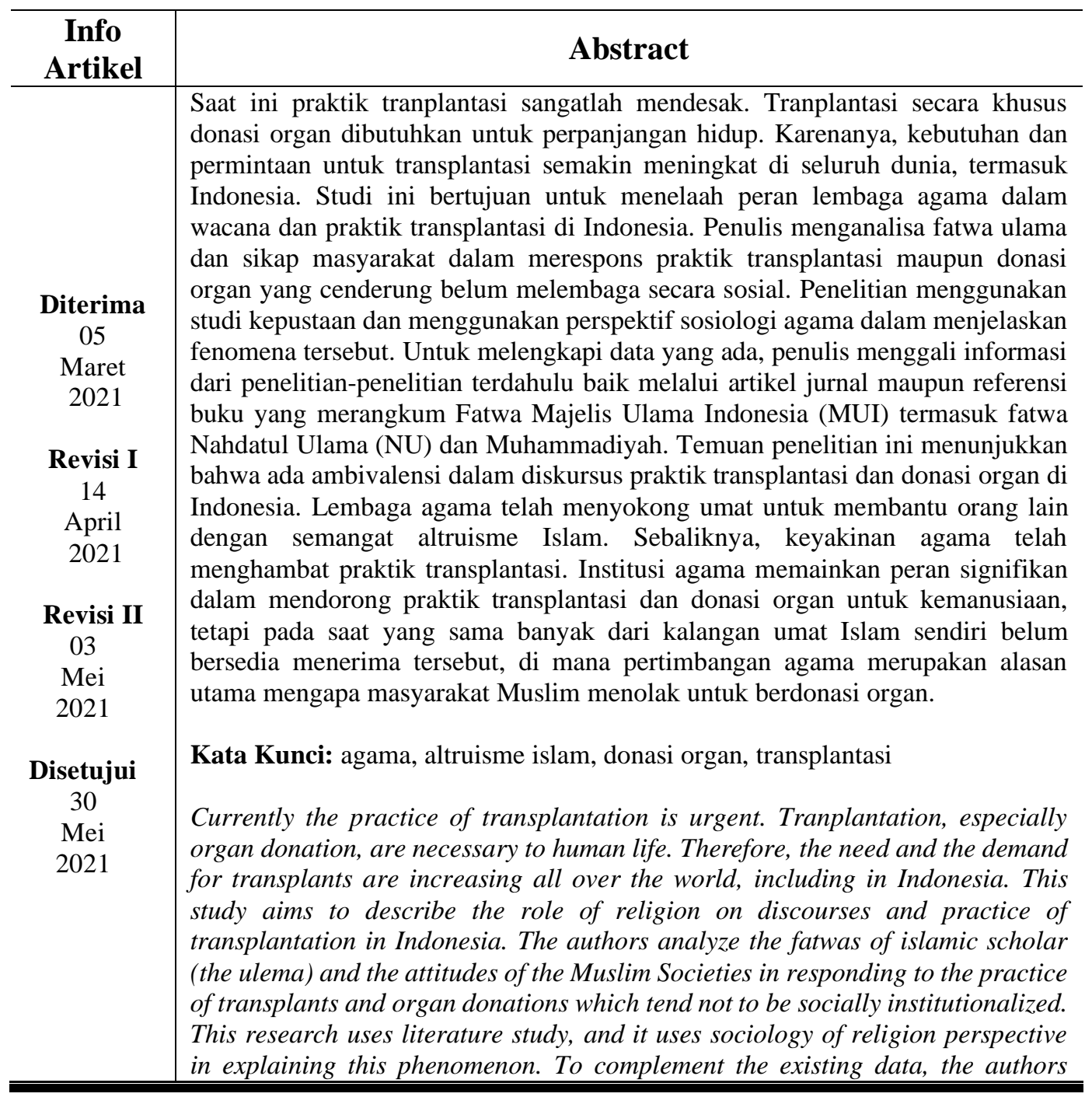


search information from previous studies through both journal articles and book references that summarize the Fatwa of the Indonesian Ulema Council (MUI) including the fatwas of Nahdatul Ulama (NU) and Muhammadiyah. The results of this have found that there is ambivalance within discourses of tranplantation and organ donation in Indonesia. Religious institutions have supported people to help others in the spirit of Islamic altruism. Conversely, religious beliefs have restricted the practice of transplants. The institution of religion plays a significant role to suggest transplantation of body organ for human life, however there have been many people did not yet accept it, where religious concerns is an important reason why Muslim societies decline listing to donate organ.

Keywords: islamic altruism, organ donation, religion, transplantation

\section{PENDAHULUAN}

Fenomena transplantasi dan donasi organ di Indonesia merupakan diskursus sosial ilmu kedokteran mutakhir yang tidak terlepas dari dimensi-dimensi religiusitas (Rohmah, 2018), (Damayanti, 2018). Dari waktu ke waktu, fenomena transplantasi dan donor organ membangkitkan interest bagi kalangan agama untuk merespons fenomena tersebut sebab bersinggungan dengan fenomena sosial keagamaan masyarakat. Dalam hubungan ini, kenyataan kemajuan teknologi kedokteran telah menimbulkan perdebatan yang sensitive antara dunia medis dan agama (Albar, 2012), (Saifullah, 2016).

Salah satu isu yang menarik di ranah ini adalah agama bergerak merespons isu tersebut dalam rangka merefleksi sekaligus menyesuaikan diri dengan perubahan tersebut. Hal ini semakin menegaskan peran penting lembaga agama dalam kehidupan sosial, bahwa posisi agama tidak dapat dipisahkan begitu saja dengan proses transformasi dan modernisasi seperti yang dapat disaksikan di dalam diskursus dan praktik transplantasi. Minimal kebutuhan akan interpretasi pemaknaan agama terhadap berkembangnya rasionalitas umat manusia tersebut sesuai dengan konteks dan konstelasi perkembangan sains dan ilmu pengetahuan kontemporer (Oliver, Woywodt, Ahmed, \& Saif, 2011).

Cerita sukses transplantasi (pencangkokan) organ-organ tubuh sudah banyak dilakukan dengan hasil yang menggembirakan (Johnson, Bradbury, Martin, \& Neuberger, 2014). Pada kenyataannya, sejak ditemukannya sains ini di dalam kedokteran modern donor organ telah menjadi salah satu katup penyelamat perpanjangan hidup umat manusia. Terbukti dengan kemajuan teknologi kedokteran saat ini, banyak nyawa umat manusia yang tertolong seperti para penderita, kornea, gagal ginjal, hati, paru-paru dan tulang yang mendapat pengobatan transplantasi (Rudge, Matesanz, Delmonico, \& Chapman, 2012), (Dalal, 2015).

Bersamaan dengan tumbuh suburnya praktik pencangkokan organ tubuh manusia, fenomena tranplantasi turut mempengaruhi konstruksi sosial masyarakat. Orang-orang tidak hanya mulai mempertanyakan prosedur tindakan medis dalam proses transplantasi menyangkut dimensi 
hukum, moral, dan etika kemanusiaan (Bintoro, 2016), tetapi juga masyarakat membutuhkan penjelasan transplantasi ditinjau dari sisi pandangan keagamaan (Hussain, 2018).

Di Indonesia, meski tranplantasi organ secara eksplisit diatur dalam Undang-undang (UU) kesehatan dan peraturan pelaksanaanya diatur melalui peraturan pemerintah (PP) (Firmansyah, Sylvana, \& Wijaya, 2021), tetapi persoalan ini sebenarnya tidak luput ditinjau ulang oleh lembaga-lembaga keagamaan. Melalui organisasi masyarakat (ormas) Islam misalnya, praktik transplantasi tidak terlepas dibahas dan dibuatkan fatwa yang secara terus diperbaharui mulai dari mekanismenya hingga penjelasan tentang kadar boleh tidaknya sebuah praktik donor organ tubuh (MUI, 2019). Tujuannya adalah selain meluruskan perdebatan kebolehan praktik tersebut di masyarakat, hal ini juga dalam rangka menyesuaikan dengan kondisi zaman di mana tuntutan-tuntutan kemajuan teknologi kedokteran modern pada umumnya tidak dapat dilepaskan dari konteks kehadiran norma agama.

Menelaah sepak terjang pergulatan agama dalam wacana transplantasi organ di Indonesia sesungguhnya dapat dilihat pada kontribusi ormas-ormas Islam terhadap dinamika pemikiran hukum Islam kontemporer di Indonesia (Syaiban, 2010), (Jamaa, 2017). Majelis Ulama Indonesia ( MUI ) berdasarkan ijma' para anggotanya yang terdiri dari berbagai ormas Islam seperti Nahdlatul Ulama (NU) dan Muhammadiyah, selalu memberikan pandangan hukum terkait dengan fenomena yang sering terjadi dan berkembang di masyarakat kontemporer yang bertautan dengan kesehatan dan dunia kedokteran, tidak terkecuali pandangan hukum mengenai transplantasi (Syaukani, 2015).

Gambaran di atas menunjukkan adanya campur tangan dari tiap-tiap otoritas agama terhadap praktik tranplantasi. Dengan kata lain, praktik tranplantasi maupun donasi organ menjadi isu yang banyak difatwakan oleh ulama melalui organisasiorganisasi Islam di setiap dekade untuk menjembatani pengaturan transplantasi di lini kehidupan masyarakat Indonesia yang notabenenya mayoritas Muslim. Dengan mengakumulasi tuntutan dan kebutuhan masyarakat akan pentingya praktik transplantasi, ormas-ormas Islam tersebut memberi pedoman bagi masyarakat dalam kerangka mengikuti kaidah norma-norma agama.

Kehadiran fatwa-fatwa tersebut yang secara tidak langsung mendorong psikologis umat untuk berdonasi organ, ternyata tidak sepenuhnya diterima oleh masyarakat Muslim. Dalam praktiknya, kecenderungan yang terjadi di lapangan justru masih menimbulkan pro dan kontra (Hantoro, 2019), (Sari, 2020). Tidak diragukan lagi praktik transplantasi juga kadang kala dihambat oleh agama itu sendiri. Perdebatan transplantasi tidak jarang dilatari oleh keyakinan dan prinsip keagamaan yang condong tidak ingin melembagakan praktik tersebut (Rachmawati, 2019).

Dalam konteks ini, agama mempunyai dua macam pengaruh yang saling bertentangan. Satu sisi agama turut menyokong perubahan sosial dalam hal wacana dan praktik transplantasi, namun pada sisi yang lain, ia menjadi penentang perubahan, yakni perilaku keagamaan yang umumnya memiliki pandangan negatif terhadap praktik transplantasi dan donor organ. Imbasnya, tindakan altruisme yang satu ini masih belum menjadi hal yang 
umum di Indonesia. Berdasarkan penelitian terdahulu, sebagian besar masyarakat Muslim belum terbuka terhadap tranpalantasi dan donasi organ, di mana budaya dan keyakinan agama menjadi faktor penghambat utamanya (Herani, 2017).

Memasuki milenium baru, kesadaran global mengenai pentingnya transplantasi dan donasi organ mulai terbentuk. Hal terkait, disebabkan oleh telah begitu mengkhawatirkannya ragam penyakit yang diderita populasi dunia yang memicu tingginya angka kematian tinggi. Di satu sisi, kita tidak menutup mata timbulnya "kultur pro kontra" atas praktik transplantasi pada negara-negara Muslim yang kini juga tengah menjangkiti masyarakat Indonesia. Dengan demikian, tulisan ini mencoba merentang pergulatan agama di dalam wacana dan praktik transplantasi secara khusus donor organ di Indonesia. Pertanyaan yang diajukan ialah bagaimana diskursus praktik transplantasi organ berhubungan dengan agama Islam di Indonesia? Bagaimana peranan agama dalam wacana dan praktik transplantasi dan donasi organ yang belum melembaga secara masif?

Agama (Islam) dan Diskursus Transplantasi Organ di Indonesia

Secara sederhana transplantasi dapat diartikan sebagai kegiatan memindahkan organ tubuh tersebut dari satu manusia ke manusia lainnya. Tranplantasi atau sering diistilahkan dengan pencangkokan merupakan suatu tindakan medis untuk mengganti organ tubuh pasien yang tidak berfungsi dengan organ individu lain yang sehat dan masih berfungsi (Sari, 2020). Organisasi Kesehatan Dunia (WHO) juga memberikan batasan atas defenisi atas ini. Menurut WHO, transplantation is the transfer (engraftment) of human cells, tissues or organs from a donor to a recipient with the aim of restoring function(s) in the body (Organization, 2010).

Dalam Undang-undang No. 23

Tahun 1992, Tentang Kesehatan, Pasal 1 ayat 5 dirumuskan pengertian sebagai rangkaian tindakan kedokteran untuk pemindahan alat dan atau jaringan organ tubuh manusia yang berasal dari tubuh sendiri atau tubuh orang lain dalam rangka pengobatan untuk menggantikan alat atau jaringan organ tubuh yang tidak berfungsi dengan baik (Undangundang Kesehatan, 1992). Kegiatan pemindahan alat dan atau jaringan tubuh manusia tersebut dalam rangka pengobatan atau upaya penyelamatan pihak resipien (penerima donor).

Sementara itu, donasi organ didefenisikan sebagai tindakan menyumbangkan organ tubuh untuk lain yang membutuhkan (Rudge et al., 2012). Ia biasanya berawal dari tindakan sukarela demi menyelamatkan nyawa orang lain. Namun, keputusan untuk mendonor organ tidaklah sembarangan. Banyak syarat dan kewajiban yang harus dipenuhi oleh pendonor tatkala memutuskan memberikan organ tubuhnya (Dewi, 2017). Berdasarkan defenisi ini, donor organ lebih pada tindakan memberikan atau mendonorkan organ tubuh, sedangkan transplantasi organ sudah pada taraf tindakan medis. Meski dua istilah yang berbeda, tetapi antara donor organ dan transplantasi organ saling terkait satu sama lain. Transplansi organ tidak akan dapat dilakukan jika tidak ada organ yang didonorkan. Begitu pun sebaliknya, organ yang didonorkan, diperuntukkan untuk proses transplantasi (Bintoro, 2016). Artinya, 
tujuan mendasar lahirnya transplantasi organ kebanyakan untuk tujuan mendonorkan organ itu sendiri.

Dalam fatwa Majelis Ulama Indonesia (MUI), disebutkan bahwa transplantasi adalah rangkaian tindakan medis untuk memindahkan organ dan atau jaringan tubuh manusia yang berasal dari tubuh orang lain atau tubuh sendiri dalam rangka pengobatan untuk menggantikan organ atau jaringan tubuh yang tidak berfungsi dengan baik. Pemindahan organ tubuh tersebut dimaksudkan untuk mengganti organ tubuh orang lain, yang masih mempunyai daya hidup sehat untuk menggantikan organ tubuh yang tidak sehat dan tidak berfungsi dengan baik (Ebrahim, 2007).

Sejalan dengan defenisi yang dikemukakan MUI tersebut secara substansial telah menunjukkan adanya persinggungan agama untuk memahami dan mengenali praktik transplantasi. Semenjak teknologi kedokteran modern tengah mencapai puncak keberhasilannya dalam mengembangkan pencangkokan, pada gilirannya diskursus ini merembes ke dalam prioritas yang mendesak untuk direspons oleh lembaga agama. Hal itu karena persoalannya kemajuan ini tidak sekadar kemajuan peradaban, tetapi juga masalah kehadiran agama, yakni bagaimana posisi agama tatkala berhadap-hadapan dengan kemajuan tersebut yang sesungguhnya beririsan dengan keagamaan namun tidak ada pada zaman dahulu serta tidak ada dalam kitab-kitab klasik (Hasan, 2000).

Peristiwa-peristiwa semacam ini muncul bersamaan dengan pemikiran kembali tentang signifikansi posisi agama. Satu hal yang dikhawatirkan oleh para pemuka agama seperti Islam dalam narasi perkembangan transplantasi organ, ialah transformasi dunia kedokteran yang tengah berkembang ini, jangan sampai justru menggerus nilai-nilai agama yang berurat-berakar dalam kehidupan masyarakat Muslim. Meskipun tidak eksplisit, agaknya relativisasi tradisi kemurnian agama dalam narasi tranplantasi organ merupakan faktor utama bagi munculnya penolakan masyarakat atasnya. Tatkala kemajuan teknologi kedokteran ini menggema, pada saat yang sama penganut agama Islam belum menerima dengan baik. Respons kebanyakan dari kalangan umat menunjukkan penolakan nyata atas tindakan ini.

Dalam beberapa kasus terlihat bahwa kebanyakan negara-negara dengan mayoritas Islam belum banyak melakukan transplantasi (Ali \& Maravia, 2020). Masyarakat Muslim seperti di Indonesia, masih banyak fatwa ulama yang membolehkan dan tidak membolehkan praktik ini, bahkan perdebatan yang luas baik ulama, pakar, dokter maupun pasien masih kerap terjadi (Sari, 2020). Dalam situasi ini, terdapat suatu kecenderungan di kalangan umat beragama untuk mengedepankan ajaran agama yang murni (puritanisasi). Dengan kata lain, mereka cenderung ingin mempertahankan hal-hal yang dianggap sakral sehingga menolak sains kedokteran tersebut.

Interpretasi sosiologis yang bisa ditelaah di ranah ini adalah masyarakat Islam kebanyakan senantiasa mengetengahkan orientasi kehidupan akhir. Dalam pengertian lebih luas konsepsi tranplantasi organ tidak bisa dilepaskan dari interpretasi keagamaan berkenaan "urusan-urusan kosmologis". Contoh kasus misalnya agama Islam demikian melarang ada perjual belian 
organ atau pun serampangan dalam melakukan donor tanpa memerhatikan norma-norma agama (syariah Islam), karena posisi organ tubuh dalam Islam sangat kosmologis sifatnya. Bahwa organ tubuh terkait erat dengan "pengadilan akhir sesudah kehidupan" di mana setiap anggota badan akan dipertanggungjawabkan sebab, setiap organ tersebut memiliki keterkaitan moral mengenai perilaku seseorang (si empunya) di muka bumi. Itulah mengapa kecenderungan isu transplantasi organ sering kali tidak begitu mudah diterima oleh masyarakat Muslim. Tidak hanya itu, ini juga dipengaruhi oleh silang pendapat di kalangan ulama fikih tentang hukum transplantasi organ tubuh (Shiddiq, 2017).

Walaupun praktik transplantasi mulai memperoleh dukungan besar oleh lembaga-lembaga ormas Islam di Indonesia dalam dua dekade terakhir, tapi juga kelompok Islam yang lain kebanyakan mempunyai perspektif yang berbeda dalam memaknainya. Bagi kelompok-kelompok yang menolak praktik tersebut, sudah hampir dipastikan mereka akan menjadi penentang atas praktik transplantasi. Karena itulah, diskursus transplantasi organ di Indonesia terus bergejolak.

Fenomena di atas menghasilkan apa yang disebut Zakiyuddin Baidhawy distingsi karakter privat dan publik dari agama. Bahwa akan ditemukan kelompok-kelompok agama yang mempertahankan proses kemurnian agama (privat), dan pada saat yang sama ada desakan terhadap negara modern untuk mengedepankan kepentingan umum (publik) dalam agama mengikuti sosio-kultural lingkungan global modern (Baidhawy, 2002). Dalam konteks ini, satu sisi para pemuka agama mengambil jalan tawasuthmoderat dengan syarat atau dengan catatan tertentu dalam memandang kebolehan transplantasi organ, namun di sisi yang lain juga tidak terbantahkan bahwa masih banyak muncul dinamika konservatif dari para pemeluk agama Islam dalam hal cara pandang masyarakat yang tidak mau menyelaraskan dengan perubahan tersebut.

\section{METODE}

Penelitian ini menggunakan menggunakan metode studi kepustakaan dengan cara mengumpulkan data-data pustaka, membaca, mencatat dan mengolah bahan penelitian (Mustika, 2008). Penulis tidak hanya mengidentifikasi penelitian yang konsen terhadap isu transplantasi dan donasi organ yang dipotret dari sisi sosial keagamaan oleh para peneliti dari berbagai latar belakang bidang ilmu, tetapi juga mempelajari fatwa-fatwa tentang donor organ yang dikeluarkan oleh berbagai organisasi Islam di Indonesia seperti Majelis Ulama Indonesia, Nahdatul Ulama, dan Muhammadiyah sebagai Organisasi Masyarakat Islam (ormas) terbesar di Indonesia. Demi menjaga keilmiahan, penulis mengumpulkan buku yang memuat fatwa ormas tersebut dan dokumen fatwa yang dipublikasikan di media internet serta mencari sumber bacaan yang revelan baik dari berita harian nasional maupun jurnal dan buku yang membahas topik terkait dengan transplantasi dan donasi organ. Setelah mengumpulkan data, penulis menggarisbawahi intisari bacaan, kemudian mereduksi data hasil pembacaan atau intisari ke dalam topiktopik paragraf. Analisis terhadap data- 
data temuan tersebut kemudian dijelaskan menggunakan pendekatan teori sosiologi agama dalam menelaah fenomena pergumulan agama dalam wacana dan praktik transplantasi dan donasi organ di Indonesia.

\section{HASIL DAN PEMBAHASAN Pertautan Altruisme Islam dengan Transplantasi dan Donasi Organ}

Setiap agama yang ada di dalam masyarakat, memiliki sumber moral dan tata nilai bagi setiap penganutnya. Agama memiliki seperangkat muatan nilai yang mempengaruhi semua aspek kehidupan masyarakat, sehingga agama tidak dapat dapat dipisahkan dari dinamika kehidupan sosial (Hanani, 2011). Tujuan mendasar dari setiap norma agama tersebut adalah membawa kemaslahatan hidup bagi setiap individu bahkan komunitas dalam kehidupan masyarakat. Inilah mengapa setiap agama identik dengan altruisme.

Secara etimologis istilah altruisme merupakan diksi yang mengacu pada kebaikan untuk orang lain. Menurut Kamus Sosiologi konsep altruisme biasanya dibedakan dari egoisme dan individualisme (Abercrombie, Hill, \& Turner, 2010). Dalam pengertian tersebut, altruisme merupakan pengejawantahan dari sikap yang mementingkan kebutuhan dan kepentingan orang lain. Altruisme merujuk pada sikap dan tingkah laku yang dilakukan oleh seseorang dengan penuh kerelaan dan keihklasan memberikan bantuan kepada orang lain. Seseorang tidak hanya bersimpati dan berempati terhadap individu lain, tetapi juga mampu berkorban dan memberikan sesuatu yang bernilai bagi orang lain meskipun dirinya juga sedang memerlukan (Hidayati, 2016).
Menurut Myers dalam (Robbitha, Rizka Asnenia \& Herani, 2018) altruisme memiliki tiga aspek utama, yaitu; (1) memberi perhatian pada orang lain, (2) membantu orang lain, (3) mengutamakan kepentingan orang lain. Mereka yang memiliki semangat altruisme akan peduli dan membantu orang lain meski tidak ada keuntungan yang ditawarkan atau tidak mendapatkan balasan atas pemberian yang diberikan kepada orang lain.

Jika dilacak sumber tekstualnya, moral altruisme memiliki sandaran kuat dari doktrin semua agama sebab, altruisme lebih banyak dilatari oleh nilai-nilai humanitarianisme yang ada pada agama. Dengan kata lain, altruisme bukanlah sejenis netralisme kosong, yang bersifat prosedural semata, melainkan suatu pandangan hidup yang berakar dalam ajaran agama. Melalui altruisme agama, setiap orang dituntun menyemai cinta kepada sesama dan memberi penghormatan terhadap harkat dan martabat kemanusiaan. Dalam Islam, misalnya, agama Islam memiliki perhatian lebih terhadap isu kemanusiaan, di mana salah satu misi utamanya adalah menyelamatkan hidup atau memberi maslahat bagi kehidupan (Al-Harthi \& Alzahrani, 2015).

Berkenaan dengan wacana transplantasi dan donasi organ, Islam merespons fenomena tersebut dengan sederetan fatwa tentang bolehnya melakukan tindakan tersebut. Formulasi tentang transplantasi dan donasi organ telah disepakati oleh ulama-ulama Islam dunia di mana lembaga-lembaga agama Islam melalui berbagai fatwa membolehkan melakukan pencangkokan (Arbour, AlGhamdi, \& Peters, 2012). Dari sini terlihat bahwa agama Islam tidak hanya berusaha menemukan jawaban praksis dan 
teoritis terhadap problem masyarakat yang berkaitan dengan problem sosial kesehatan yang didasarkan pada agama maupun ilmu pengetahuan, tetapi juga mengutamakan kepentingan orang lain dan kebaikan bersama. Seperti agamaagama modern lainnya, Islam demikian meninggikan "kebaikan sosial" sebagai dimensi yang esensial dari sistem simbol keyakinan. Ini misalnya dapat ditelaah pada konsepsi "nyawa manusia". Nilai nyawa dalam pandangan Islam begitu tinggi. Tidak peduli nyawa seorang Muslim atau nonMuslim, ia tetaplah harus dijaga. Terkait dengan ini, Al-quran telah menjelaskan bahwa "Barangsiapa yang memelihara seorang manusia, maka seolah-seolah dia telah memelihara kehidupan manusia semuanya" (Q.S Al-Maiyah: 32).

Dalam konteks tersebut di atas, pintu masuk hadirnya transplantasi dan donasi organ untuk keselamatan jiwa orang lain, sangat beririsan dengan kehadiran agama Islam terutama anjuran bagi umatnya memelihara jiwa seseorang. Sebagai contoh misalnya, seseorang yang mengalami gejala gagal ginjal, untuk mempertahankan hidupnya diperlukan transplantasi atau donasi organ dari orang lain, sebab jika tidak ada tindakan medis lanjutan, orang tersebut secara potensial mengalami kematian. Di sinilah diperlukan pencangkokan (transplantasi dan donasi organ) oleh setiap insan masyarakat Muslim sebagai wujud tanggung jawab sosialnya dalam menyelamatkan jiwa orang lain.

Seturut dengan fenomena transplantasi dan donasi organ tubuh, dalam Islam seperti yang telah dikemukakan sebelumnya, ada kewajiban bagi para penganutnya untuk senantiasa menolong satu nyawa.
Demikian pentingnya, sampai-sampai dianalogikan seperti meyelamatkan seluruh umat manusia. Tindakan semacam ini, meminjam pandangan sosiolog Robert N. Bellah tindakan keagamaan yang dikonsepsikan sebagai identik dengan keseluruhan kehidupan, bahwa ada tuntutan-tuntutan total agama dalam memelihara kehidupan yang penekanannya bersumber dari keyakinan (Bellah, 1993).

Bagi seorang Muslim, kaidah paling sederhana untuk berbuat baik kepada orang lain, atau biasa disebut altruisme, karena ajaran agama yang menjadi patokan referensi dalam bertindak (Arif, 2017). Dalam agama Islam, misalnya, nilai universal fenomena berbuat baik kepada orang lain atau menolong orang lain adalah bagian dari misi sosial agama Islam itu sendiri. Satu hal yang patut diingat, bahwa agama Islam sangat menyokong tindakan berbagi dan memberi bagi sesama kepada setiap pemeluknya, sebab akan dibalas kebaikannya setimpal dengan perbuatan baiknya. Dengan demikian, tindakan sosial transplantasi dan donasi organ sesungguhnya secara konsekuen juga berlaku orientasi misi profetik tersebut yang disesuikan dengan konteks zaman dan kebutuhannya.

Meski tidak mudah, beberapa tulisan ilmiah berusaha menganalisis motif atau alasan melakukan transplantasi dan donasi organ. Menggunakan pendekatan psikologi, Ika Herani merumuskan tiga faktor yang memengaruhi keputusan orang untuk berdonasi organ tubuh. Dalam temuan tersebut disebutkan bahwa pengambilan keputusan untuk mendonorkan organ tubuh kepada orang lain adalah informasi yang dimiliki berkaitan dengan donor organ telah cukup, tingkat 
pendidikan kedua subyek cukup tinggi dan memiliki pribadi prososial (Herani, 2017). Dalam konteks pribadi prososial, ini berelasi kuat dengan altruisme sosial. Individu yang mampu menempatkan dirinya dalam perbuatan baik untuk kepentingan orang lain, akan tergerak di mana agama merupakan salah satu menjadi pendorong untuk berdonor. Ini dikuatkan dengan temuan penelitian lain bahwa keputusan seseorang untuk melakukan transplantasi, salah satunya karena altruisme agama yang memoderasi perilaku seseorang untuk mendonorkan organnya (Elsa Adelia Nurrachma, Budhi Haryanto, 2018).

Dalam analisa dan interpretasi sosiologisnya, tindakan semacam ini dinamakan tindakan rasional berorientasi nilai oleh sosiolog Max Weber (Weber, 2012), yaitu kebaikan yang ada hubungannya dengan nilai absolut dan nilai akhir bagi individu, yang dipertimbangkan secara sadar untuk mencapai tujuan. Memberi donasi organ tubuh, misalnya, dengan melakukan tindakan tersebut seseorang meyakini bahwa dengan berbagi, ia akan menjadi hamba Allah yang meraih pahala. Dengan kata lain, interpretasi pemaknaan agama telah membawa penganutnya memilih berbagi donasi organ yang dimaksudkan sebagai jalan untuk diridhai dan meraih surga di akhirat kelak.

Di lihat dari perspektif teori tindakan rasional berorientasi nilai, transplantasi maupun donor organ yang dilakukan oleh seseorang atas dasar agama ini adalah, pemberian yang bermakna kebaikan sosial. Para pendonor boleh saja menolak secara lahiriah untuk berdonasi. Tetapi karena dorongan kebaikan yang bersumber dari agama membuat mereka bersemangat berkorban buat orang lain. Tindakan atau keputusan untuk berbagi oleh pendonor tersebut ditentukan oleh janjijanji balasan akhirat. Mereka memaknai sebagai kebaikan buat orang lain sesuai anjuran agama dan kemudian bertindak atas dasar makna agama tersebut.

\section{Pergumulan Fatwa Organisasi Masyarakat Islam: Membatasi atau Menyetujui?}

Kemajuan di bidang sains yang tengah berkembang dalam berbagai bidang kehidupan seperti transplantasi organ, merupakan realitas sosial yang tidak terelakkan di abad ini. Dalam prosesnya itu, dapat dikatakan bahwa perubahan tersebut senantiasa mengadaptasikan agama, sebaliknya para pembuat fatwa agama (ulama) mencoba beradaptasi sesuai dengan peradaban yang membawanya. Ini merujuk pada bagaimana umat Islam melalui fatwa ulama mengkaji persoalan-persoalan kehidupan kontemporer lalu berupaya menyesuikan diri meski tetap memerhatikan kaidah-kaidah agama (fiqih).

Indonesia sebagai salah satu negara Muslim terbesar di dunia, tidak dapat dipungkiri aturan agama tidak bisa dilepaskan dari kehidupan masyarakatnya, salah satu di antaranya, yaitu praktik transplantasi maupun donasi organ. Lembaga-lembaga agama senantiasa berupaya mengatur tindakantindakan sosial penganutnya sehingga para pemeluknya tersebut tidak melenceng dari nilai-nilai ajaran agama secara khusus Islam yang diyakini oleh masyarakat Indonesia pada umumnya.

Fenomena keterlibatan institusi agama dalam percaturan praktik transplantasi di Indonesia, secara umum dapat dilihat dari keterlibatan lembaga- 
lembaga agama di Indonesia mengatur catur norma melalui fatwa organisasi masyarakat (ormas) Islam. Pandangan masing-masing lembaga sosial keagamaan tersebut telah membentuk cara pandang masing-masing dalam memahami praktik transplantasi yang kemudian menjadi dasar bagi masyarakat dalam pelembagaan transplantasi dan donasi organ di dalam kehidupan sosial umat beragama.

Secara historis, peran agama dalam praktik transplantasi di Indonesia, secara umum dapat dilihat dari kontribusi organisasi-organisasi Islam melalui fatwanya. Pertama, sejak tahun 1950 Majelis Ulama Indonesia (MUI) mengeluarkan fatwa tentang transplantasi organ tubuh manusia. Dalam fatwa tersebut disampaikan bahwa transplantasi organ diperbolehkan. Hal yang tidak diperbolehkan adalah jual beli organ tubuh atau MUI melarang perjual belian dan perdagangan organ manusia. Tidak berhenti sampai di situ, MUI secara berturut-turut terus mengeluarkan fatwa yang bersinggungan dengan transplantasi seiring dengan realita perkembangan transplantasi (MUI, 2006), (Ahmad, 2012), (Hantoro, 2019). Kedua, di tahun 1981, Latjah Batsul Masa'il Pengurus Besar Nahdatul Ulama (PBNU) mengeluarkan fatwa tentang cangkuk (transplantasi) secara khusus mata, hati, serta jantung. Dalam pandangan PBNU, praktik donor organ tubuh hanya boleh dilakukan apabila memenuhi syarat (1) sangat dibutuhkan, organ tubuh tidak diperbolehkan kecuali organ manusia, antara pendonor dan penerima memiliki kesamaan agama (Zahro, 2004). Ketiga, keputusan Mufti Muhammadiyah di tahun 1990. Dalam fatwa tersebut, disepakati bahwa donor organ manusia hanya diperbolehkan jika untuk alasan penyembuhan setelah usaha dalam penyembuhan tidak sukses dan praktik tersebut tidak membahayakan bagi penerima donor (Muhammadiyah, 1990).

Fatwa-fatwa di atas sesungguhnya penjabarannya amatlah luas. Dalam kondisi pesatnya perkembangan transplantasi, fatwa ulama diperlukan untuk menjawab kebingungan umat. Ini tentu dimaksudkan sebagai langkah tokohtokoh agama untuk menenangkan umat sekaitan dengan kebolehan praktik transplantasi. Sebab, masyarakat kadang kala resah jika tidak ada jalan keluar dari kerumitan yang tengah dihadapinya. Karena itulah penjelasan fatwa muncul karena adanya kebutuhan masyarakat terhadap penjelasan ulama terkait hukum dalam agama.

Pertanyaannya kemudian adalah, apakah fatwa tentang transplantasi organ di atas membatasi atau menyetujui? Sepintas lalu dari rentetan fatwa tersebut, adalah nyata bahwa betapa agama menyediakan seperangkat cara berpikir rasionalteologis dalam melihat fenomena donor organ. Fatwa tersebut menyiratkan bahwa agama telah hadir menjawab problem-problem sosial yang mengitari masyarakat kontemporer seperti isu tentang pentingnya transplantasi. Artinya, sekalipun pengaturan transplantasi telah diatur sedemikian rupa oleh pemerintah agar setiap prosesnya tidak disalahgunakan, namun agama secara khusus Islam juga menyediakan seperangkat aturan bagi umatnya dalam merespons isu donor organ yang tengah menggelinding dan dibutuhkan saat ini.

Catur norma di atas telah menunjukkan indikasi bahwa 
kecenderungan lembaga agama tidak melepaskan begitu saja tradisi norma keagamaan dalam praktik transplantasi dan donasi organ. Terkait dengan kehadiran fatwa-fatwa di atas yang dirangkum dalam berbagai referensi, menurut hemat penulis praktik tranplantasi dan donasi organ disetujui oleh lembaga agama di satu sisi, dan pada saat yang bersamaan agama membatasi keluwesan transplantasi itu sendiri. Namun demikian, respons fatwa ini setidaknya dilatari oleh tiga faktor; pertama, menghindari praktik transplantasi yang merugikan. Ada kekhawatiran bahwa praktik transplantasi maupun donasi organ bisa saja mengarah ke praktik perjual belian jika donor organ tidak dikontrol oleh lembaga agama. Sebab aturan hukum negara tidaklah cukup kuat untuk menghindari praktik perjual belian organ itu sendiri (Laki, 2015).

Kedua, menjamin donor organ telah sesuai dengan syariah. Misalnya, larangan melakukan cangkok dengan cara yang dilarang termasuk menggunakan benda haram. Dalam konteks praktik transplantasi masyarakat Indonesia, bahwa yang melatari lahirnya fatwa-fatwa tersebut didasari dengan permintaan berbagai elemen masyarakat. Ini dikuatkan dengan pernyataan MUI sendiri bahwa adanya pertanyaan dari masyarakat, dan juga dari tim medis secara khusus Kementerian Kesehatan tentang status hukum tentang transplantasi organ atau jaringan tubuh orang lain yang memiliki kesamaan, merupakan salah satu alasan mengapa fatwa tentang transplantasi organ selalu diperbaharui (Hantoro, 2019).

Ketiga, mendukung transplantasi untuk kemaslahatan hidup umat manusia. Lahirnya fatwa organisasi Islam dalam praktik transplantasi dilatari oleh prinsip sesuatu yang baik menurut akal (mashlahah mursalah) dengan pertimbangan melihat (mengambil manfaat dan menolak mudharat (mafsadah) yaitu, agama menganjurkan atau mengutamakan prinsip kebaikan untuk semua untuk kepentingan yang nyata dan diperlukan oleh masyarakat. Lahirnya fatwa organ oleh para pemeluk agama karena dorongan keyakinan agamanya, menggambarkan suatu aspek penting dalam hal altruisme sosial agama. Dalam ruang lingkup yang lebih umum dapat dikatakan, bahwa lembaga agama (Islam) telah menyokong praktik transplantasi dan donasi organ pada saat ini untuk kepentingan sosial.

Lembaga-lembaga agama di Indonesia sedikit banyak merespons dan menerima agenda pembaharuan di dalam dunia kedokteran modern namun tetap tidak mengabaikan interpretasi atas keyakinan agama. Para ulama menyepakati kebolehan transplantasi tetapi tidak semuanya bisa digeneralkan seperti tidak boleh mendonasikan organ reproduksi, organ genital, dan otak. Memang tidak banyak yang menyangkal bahwa teknologi kedokteran yang memfasilitasi transplantasi maupun donasi organ, akan membawa kebaikan sosial, karena berbasis pada pemanfaatan organ yang dapat ditransfer ke orang lain, yang keberadaannya dapat menolong orang lain. Bagi mereka yang tengah sakit dan kehilangan fungsi-fungsi organ tubuh, donasi organ pada akhirnya akan dapat memperpanjang peluang hidupnya atau bisa memperpanjang jangka waktu seseorang untuk bertahan dari penyakit yang dideritanya dengan pemberian donor organ seperti penyakit gagal 
ginjal. Oleh sebab itu, wajar jika para ulama Muslim melahirkan rekomendasi fatwa demi kemaslahatan hidup umat manusia. Namun demikian, perlu dipahami bahwa kebaikan-kebaikan tersebut karena atas nama kemanusiaan, tidak berarti mengabaikan norma-norma agama.

Secara sosiologis, pada proses ini, mau tidak mau peran keagamaan menjadi semakin terlihat di masyarakat sebab institusi sosial secara langsung dituntut menyesuikan dengan pengakuan lembaga agama. Walaupun organisasi-organisasi Islam tersebut tidak memiliki landasan resmi yang mengikat dalam konstitusi negara, namun lembaga agama dalam kenyataannya mampu melahirkan norma umum yang secara efektif mempengaruhi masyarakat sebab baik pemerintah, tenaga medis, maupun masyarakat selama ini menjadikan fatwa sebagai pedoman dengan alasan mempertimbangkan aspek syar'i pada setiap tindakan medis (MUI, 2019).

Tulisan ini berargumen bahwa adanya perhatian lembaga agama Islam terhadap praktik transplantasi satu sisi, turut mendorong pengembangan praktik donasi organ dalam dunia kedokteran. Lembaga agama yang memberi legitimasi pengaturan donor misalnya, selain membatasi hal-hal yang boleh dilakukan dalam praktik donor, hal ini juga secara tidak langsung turut mendorong para pemuluknya untuk berdonasi. Dengan kata lain, ramburambu teologis yang disediakan oleh lembaga agama, pada gilirannya akan memberi kepastian bagi pemeluknya dalam merespons kebutuhan akan pentingnya kehadiran kedokteran modern. Namun demikian, dimensi praktik religius dan komitmen pada kesakralan agama tetap tidak diabaikan begitu saja pada sisi yang lain.

\section{Masyarakat Muslim Indonesia dan Kultur Donasi Organ, Dinamika dan Tantangannya}

Seperti pada penjelasan sebelumnya, di samping keberhasilan lembaga agama melalui ijma' ulama tentang anjuran berdonor, terdapat juga sebuah paradoks yang kemudian muncul di antara anggota masyarakat. Masih banyak perdebatan tentang boleh dan etis tidaknya dilakukan donor organ. Awal dari rekomendasi fatwa adalah memberi rambu-rambu kepada umat dalam melakukan praktik tranplantasi untuk donasi organ, namun nyatanya niat awal untuk berbagi harus berhadapan kurangnya minat dan perhatian masyarakat Indonesia untuk berdonasi.

Sebelum dan sesudah dikeluarkannya fatwa oleh berbagai organisasi Islam baik dari perhimpunan ulama dunia maupun di Indonesia, masyarakat masih belum sepenuhnya mampu menerima fatwa tersebut. Dinamika dan tantangannya di ranah ini adalah ada pro kontra yang masih merembet pada persepsi masyarakat Muslim karena dari masing-masing anggota masyarakat belum sepenuhnya menerima praktik tersebut. Bahwa ada anggota yang pasif, ada anggota mengupayakan berperan termasuk ada yang terang-terang menolak karena dianggap kurang etis. Di antara yang menjadi penyebabnya ialah, donor organ tidak hanya dirasa kurang relevan dengan kultur masyarakat Indonesia, tetapi juga masih adanya mispersepsi interpretasi terhadap teks-teks keagamaan.

Dalam kondisi ini, ada kesan ketidakpedulian kebanyakan umat Islam 
terhadap tanggung jawab sosialnya dalam hal transplantasi. Umat Islam seolah tidak mengakomodir praktik transplantasi sebab kurangnya komitmen bersama dalam hal mengkampanyekan pentingnya donor organ untuk kemanusiaan sebagaimana cita-cita Islam yang menjadi rahmah bagi semesta. Salah satu tanda yang mengindikasikan fenomena ini adalah bahwa justru di negara-negara mayoritas non-Muslim yang kita saksikan suatu keterbukaan baru terhadap praktik transplantasi dan donasi organ. Sebaliknya umat Muslim, sekalipun berada di negara-negara maju seperti Amerika juga memperlihatkan bahwa mereka pada umumnya memiliki pandangan yang lebih negatif terhadap donasi organ dan transplantasi (Padela \& Auda, 2020).

Melihat fakta-fakta tersebut, seperti yang telah dijelaskan sebelumnya bahwa sikap tertutup ini kadangkala memang dipengaruhi oleh keyakinan-keyakinan keagamaan. Sebagian besar masyarakat Muslim masih sering dipugari dengan kontradiksi keyakinan agama. Bahwa organ tubuh adalah milik Tuhan dan akan dipertanggung jawabkan oleh si empunya baik di dunia maupun akhirat (Hamdy, 2012). Jadi, sebagai misal, pemikiran umum masyarakat Islam adalah setelah alam kehidupan ditinggalkan dalam hakekatnya, maka setiap individu akan berhadap-hadapan dengan segenap misteri yang dijelaskan oleh agama tentang pertanggungjawaban anggota tubuh terhadap Tuhan (kehidupan di kemudian hari).

Dalam konteks tersebut, muncul reaksi masyarakat Islam yang mengarah pada sikap fundamentalisme, yakni masyarakat Islam umumnya menolak segala hal yang berbau modern. Dengan kata lain, ekspresi tersebut adalah bagian dari perlawanan terhadap modernitas masyarakat modern, ditambah kuatnya perspektif keagamaan mainstream di dalam masyarakat yang menempatkan transplantasi dan donasi organ sebagai sesuatu yang tidak pernah diajarkan oleh agama. Agama yang dipahami sempit tersebut, pada akhirnya menempatkan transplantasi dan donor organ pada posisi yang bukan menjadi kebutuhan masyarakat dalam kehidupan sosial.

Jika mendasarkan diri pada fatwa-fatwa tentang kebolehan melakukan tansplantasi dan donor organ, tantangan di atas sesungguhnya bisa di temukan solusi rasionalnya dalam praksis agama yang berpijak pada altruisme Islam, bahwa umat Islam adalah sekelompok sosial yang harus mengejawantahkan dirinya secara konkret ke dalam penghayatan diri atas kepentingan hidup orang lain dan martabat kemanusiaan. Tatkala umat sedemikian terpenjara dengan hasrathasrat diri sendiri dengan alasan tidak ingin menodai agama, maka hal semacam ini meniadakan kemaslahatan hidup bersama dalam alam sosial dan mempersempit batas-batas kasih sayang (rahmah) dalam agama yang mencakup segenap makhluk hidup dan seluruh alam semesta.

Namun demikian, dinamika dan tantangan tersebut bukanlah fenomena yang berdiri sendiri. Hal ini adalah akibat pengaruh lembaga agama sebagai sebuah sistem budaya. Agama sebagai sistem simbol dan budaya, meminjam istilah Clifford Geertz belum berperan secara masif bagi pengembangan atau pelembagaan transplantasi di kehidupan sosial. Ungkapan ini mengandung makna bahwa tindakan atau aksi sosial 
dalam donasi organ, sangat ditentukan oleh nilai-nilai ajaran agama yang diyakini oleh seseorang. Sebab, pengaruh agama terhadap manusia tidak hanya berhubungan dengan persoalan sakral, tetapi juga meratifikasi psikologi manusia untuk berubah dari satu kesadaran ke kesadaran lainnya (Hanani, 2011). Oleh sosiolog Max Weber disebut, agama dapat melecut dan membangkitkan motivasi manusia untuk terus bertindak sesuai keyakinannya (Weber, 2012).

Dengan demikian, menurut hemat penulis ada dua faktor dominan yang menjadi penyebab utama mengapa praktik transplantasi maupun donasi organ masih minim dilakukan seperti yang terjadi pada negara-negara Muslim seperti Indonesia; Pertama, donasi organ belum menjadi kebiasaan umum masyarakat Muslim. Kurangnya literasi agama dan pemahaman tentang donasi organ membuat masyarakat Muslim tidak lazim dengan praktik transplantasi. Terbukti di negara-negara dengan mayoritas Islam justru diliputi berbagai masalah dan masih sedikit sekali tindakan mendonorkan organ tubuh terhadap orang lain (Hamdy, 2012), (Morad, 2013), (Hassan ChamsiPasha \& Albar, 2017). Dalam konteks ini, hambatan utamanya ialah masih sedikitnya kesadaran para tokoh agama untuk mengkampanyekan tanggung jawab sosial transplantasi dan pentingnya donasi organ untuk harkat dan martabat kemanusiaan. Amatlah penting tokoh agama menjadi garda terdepan dalam persoalan ini. Mengapa? Sebab umumnya orang hanya akan setuju untuk menyumbangkan organ jika mereka didukung oleh komunitas dan pemimpin agama (Al-harthi \& Alzahrany, 2015).
Kedua, minimnya rumah sakit bercorak Islam yang mendukung dan menopang praktik transplantasi. Usaha untuk mengembangkan rumah sakit Islam yang disokong teknologi kedokteran modern masih kurang. Ini membuat praktik transplantasi di rumah sakit sangat minim dilakukan. Fenomena tersebut diperkuat dengan sejumlah data bahwa kebanyakan praktik transplantasi maupun donor organ di Indonesia justru diinisiasi oleh rumah sakit konvensional dan swasta bukan rumah sakit bercorak agama (Sinaga, 2007).

\section{PENUTUP}

Berdasarkan hasil penelitian dapat disimpulkan bahwa terdapat ambivalensi kehadiran agama dalam diskursus dan praktik transplantasi dan donasi organ di Indonesia. Seiring dengan perkembangan dan penyesuaian zaman, agama telah mengambil peran penting dalam pergumulan praktik transplantasi. Lembaga agama tidak hanya menyediakan seperangkat aturan tentang donor organ, melainkan juga institusi agama memberikan sokongan secara psikologis kepada umatnya untuk berbagi donasi organ. Hal tersebut dapat dilihat dari perhatian lembaga agama dalam mengatur praktik donor organ di mana telah banyak fatwa dan konsensus ulama dari berbagai muktamar lembaga organisasi Islam di Indonesia yang membolehkan praktik transplantasi. Namun demikian, ada alasan kuat untuk percaya bahwa agama memiliki peranan penting sebagai alasan utama mengapa pasien menolak transplantasi. Dari dahulu hingga sekarang, juga tidak dinafikan bahwa keyakinan agama dan sistem kelembagaan agama acap kali masih menjadi penghambat utama transplantasi organ secara khusus 
donasi organ, sehingga peluang penerapan praktik transplantasi dan donor organ secara masif belum dapat dilakukan di Indonesia.

Oleh karena itu, melihat dinamika dan tantangan di negaranegara Muslim seperti Indonesia, peran lembaga agama sejatinya senantiasa hadir sebagai media-penjawab terhadap isu-isu krusial kontemporer seperti tanggung jawab sosial agama dalam masalah pengadaan donor organ manusia. Nilai-nilai altruisme Islam yang disokong oleh perangkat norma berupa fatwa dapat direfleksikan kembali untuk mengaktualisasikan transplantasi maupun donor organ, sebab panduan agama sebagai landasan moral dalam konteks ini, sudah sangat jelas, bahwa motivasi ajaran agama untuk menyelamatkan nyawa orang lain dapat diterapkan dalam praktik transplantasi dan donasi organ demi menjaga kemaslahatan hidup umat manusia dalam kehidupan sosial di permukaan bumi.

\section{UCAPAN TERIMA KASIH}

Kami berterima kasih kepada pengelola Jurnal "Pusaka" Jurnal Khazanah Keagamaan Balai Penelitian Penelitan dan Pengembangan Kementerian Agama Makassar atas kesempatan untuk menerima tulisan kami. Penulis berterima kasih atas dukungan dari Ketua Program Studi Sosiologi Agama Fakultas Ushuluddin Adab dan Dalwah Institut Islam Negeri Parepare, Sulawesi Selatan Indonesia. 


\section{DAFTAR PUSTAKA}

Abercrombie, N., Hill, S., \& Turner, B. S. (2010). Kamus Sosiologi. Yogyakarta: Pustaka Pelajar.

Ahmad, C. (2012, February). Fatwa MUI: Cangkok Organ Tubuh, Boleh. Republika. Retrieved from https://www.republika.co.id/berita /dunia-

islam/fatwa/12/02/15/lzfbemfatwa-mui-cangkok-organ-tubuh-

Al-harthi, H. A., \& Alzahrany, O. A. (2015). Perceptions and Attitudes of Saudi Adult Population Toward Organ Donation, Taif , Saudi Arabia. International Journal of Medical Science and Public Health, 4(8), 1113-1120. https://doi.org/10.5455/ijmsph.201 5.28042015235

Albar, M. (2012). Organ Transplantation: A Sunni Islamic Perspective. Saudi Journal of Kidney Diseases and Transplantation, 23(4), 817.

Ali, M., \& Maravia, U. (2020). Seven Faces Of A Fatwa: Organ Transplantation And Islam. Religions, 11(2), 99.

Arbour, R., AlGhamdi, H. M. S., \& Peters, L. (2012). Islam, Brain Death, and Transplantation: Culture, Faith, and Jurisprudence. AACN Advanced Critical Care, 23(4), 381-394.

Arif, M. (2017). Filantropi Islam Fikih untuk Keadilan Sosial. Yogyakarta: Magnum.

Baidhawy, Z. (2002). Ambivalensi Agama Konflik \& Kekerasan. Yogyakarta: LESFI.

Bellah, R. . (1993). Evolusi Agama. In Agama dalam Analisa dan Interpretasi Sosiologis (Terjemahan, p. 330). Jakarta: Raja
Grafindo Persada.

Bintoro, A. (2016). Memahami Nilai Etika Dan Moral Donasi Organ. Jurnal Orientasi Baru, 25(1).

Dalal, A. R. (2015). Philosophy of Organ Donation: Review of Ethical Facets. World Journal of Transplantation, 5(2), 44.

Damayanti, F. N. (2018). Paradigma Penegakan Hukum Transplantasi Organ Berbasis Transedental. Prosiding Seminar Nasional \& Call for Papers Hukum Transendental.

Dewi, M. (2017). Kebijakan Transplantasi Ginjal di Indonesia. Makassar.

Ebrahim, A. F. M. (2007). Fikih Kesehatan (Terjemahan). Jakarta: Serambi Ilmu Semesta.

Elsa Adelia Nurrachma, Budhi Haryanto, N. H. S. (2018). Intention to Donate Kidney In Indonesia: The Role of Financial Incentive, Perceived Risk, and Altruism. Manajemen, Jurnal Ilmiah, 8(3), 463-476.

Firmansyah, Y., Sylvana, Y., \& Wijaya, H. (2021). Transplantasi Organ Tubuh Manusia Dalam Perspektif Hukum Positif Indonesia. Jurnal Medika Hutama, 2(02), 524-532.

Hamdy, S. (2012). Our Bodies Belong To God: Organ Transplants, Islam, And The Struggle For Human Dignity In Egypt. London: Univ of California Press.

Hanani, S. (2011). Menggali Interelasi Sosiologi dan Agama. Bandung: Humaniora. Bandung: Humaniora.

Hantoro, J. (2019, June). MUI Keluarkan Fatwa Soal Transplantasi Organ Tubuh. Tempo. Retrieved from https://nasional.tempo.co/read/121 6150/mui-keluarkan-fatwa-soaltransplantasi-organ- 
tubuh/full\&view $=$ ok

Hasan, A. (2000). Masail Fiqhiyah AlHaditsah Pada Masalah-Masalah Kontemporer Hukum Islam. Jakarta: Raja Grafindo Persada.

Hassan Chamsi-Pasha, F., \& Albar, M. A. (2017). Islamic Medical Jurisprudence Syllabus: A Review in Saudi Arabia. Med J Malaysia, 72(5), 279.

Herani, I. (2017). Organ Donation? Why Not Keputusan Untuk Mendonor Organ Tubuh. Psikovidya, 21(2), 1-13.

Hidayati, F. (2016). Konsep Altruisme dalam Perspektif Ajaran Agama Islam. Psikoislmika, 13(1), 59-63.

Hussain, Y. Bin. (2018). Studi Komparatif Antara Yusuf Qardhwi dan Masjfuk Zuhdi Mengenai Hukum Donor Organ Tubuh Bagi Pendonor yang Masih Hidup. Universitas Islam Negeri Sultan Syarif Kasim Riau.

Jamaa, L. (2017). Kontribusi Muhammadiyah terhadap Dinamika Pemikiran Hukum Islam Kontemporer di Indonesia. $A l$ Ihkam, $12(1), \quad 128$. https://doi.org/10.19105/alihkam.v11i2.779

Johnson, R. J., Bradbury, L. L., Martin, K., \& Neuberger, J. (2014). Organ Donation and Transplantation in The UK-The Last Decade: A Report from The UK National Transplant Transplantation, 97, S1-S27.

Laki, Y. A. (2015). Tindak Pidana Perdagangan Organ Tubuh Manusia Menurut Ketentuan Hukum Positif Indonesia. Lex et Societatis, 3(9).

Morad, Z. (2013). The New Legislation on Transplantation in Malaysia: How it Emerged and Problems
Encountered During the Process. In Conference Proceedings of the (p. 77).

Muhammadiyah, M. T. (1990). Tanya Jawab Agama. Yogyakarta: Yayasan Penerbit Pers Suara Muhammadiyah.

MUI, T. K. F. (2006). Ijma Ulama Keputusan Ijtima' Ulama Komisi Fatwa Se Indonesia III Tahun 2006. Jakarta: Majelis Ulama Indonesia.

MUI, T. K. F. (2019). Fatwa MUI Nomor 13 Tahun 2019 tentang Transplantasi Organ dan/atau Jaringan Tubuh Untuk Diri Sendiri. Jakarta.

Mustika, Z. (2008). Metode Penelitian Kepustakaan. Jakarta: Yayasan Penerbit Pers Suara Muhammadiyah.

Oliver, M., Woywodt, A., Ahmed, A., \& Saif, I. (2011). Organ Donation, Transplantation and Religion. Nephrology Dialysis Transplantation, 26(2), 437-444.

Organization, W. H. (2010). WHO guiding principles on human cell, tissue and organ transplantation. Transplant Journal of Australasia, 19(2), 26-30.

Padela, A. I., \& Auda, J. (2020). The Moral Status of Organ Donation and Transplantation Within Islamic Law: The Fiqh Council of North America's Position. Transplantation Direct, 6(3).

Rachmawati, F. (2019). Kepastian Hukum Tranplantasi Organ yang Mencerminkan Nilai Kemanusiaan. Jurnal Hukum Media Bhakti, 3(1).

Robbitha, Rizka Asnenia \& Herani, I. (2018). Peran Emosi Positif dan Emosi Negatif terhadap Altruisme Donor Organ pada Mahasiswa 
Fakultas Kedokteran di Kota Malang. Psikoislmika, 22(2), 126134.

Rohmah, L. (2018). Kontekstualisasi Hadis tentang Transplantasi. Hikmah, XIV(2), 105-131.

Rudge, C., Matesanz, R., Delmonico, F. L., \& Chapman, J. (2012). International Practices of Organ Donation. British Journal of Anaesthesia, 108(suppl_1), i48i55.

Saifullah. (2016). Transplantasi Organ Tubuh; Perspektif Hukum Islam, Hukum Positif dan Etika Kedokteran. Al-Murshalah, 2(1), 1-12.

Sari, M. (2020). Transplantasi Organ dalam Al-Quran Perspektif Tafsir Al- Maqasidi. Substantia, 22(April), 61-72.

Shiddiq, M. (2017). Transplantasi Organ Tubuh Manusia Perspektif Fatwa Bahtsul Masail Nahdlatul Ulama. Universitas Islam Indonesia.
Sinaga, U. M. (2007). Peran dan Tanggung Jawab Masyarakat dalam Masalah Pengadaan Donor Organ Manusia. Medan.

Syaiban, M. (2010). Transplantasi Organ Tubuh Orang Muslim kepada Orang Non Muslim Menurut Hukum Islam (Studi Bahtsul Masail Nahdlatul Ulama). Universitas Islam Negeri Syarif Hidayatullah Jakarta.

Syaukani, A. Z. (2015). Fatwa-Fatwa Kesehatan dan Kedokteran Majelis Ulama Indonesia Tahun 20052010. Pascasarjana Institut Ilmu Al-Qur'an (IIQ) Jakarta.

Undang-undang Kesehatan (1992). Indonesia.

Weber, M. (2012). Sosiologi Agama A Handbook (Terjemahan). Yogyakarta: IRCiSoD.

Zahro, A. (2004). Tradisi Intelektual NU: Lajnah Masa'il 1926-1999. Yogyakarta: LKis Pelangi Aksara. 